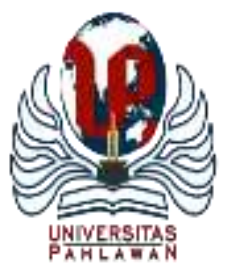

Edukatif : Jurnal Ilmu Pendidikan Volume 4 Nomor 1 Tahun 2022 Halm 38 - 52 EDUKATIF: JURNAL ILMU PENDIDIKAN

Research \& Learning in Education

https:/ledukatif.org/index.php/edukatif/index

\title{
Efektivitas Penggunaan Google Classroom sebagai Media Pembelajaran Mata Kuliah Aplikasi Komputer Mahasiswa Pendidikan Administrasi Perkantoran
}

\author{
Laili Latifathu Nafsi $^{1 凶}$, Novi Trisnawati ${ }^{2}$ \\ Universitas Negeri Surabaya, Indonesia ${ }^{1,2}$ \\ E-mail : laili.17080314087@ mhs.unesa.ac.id ${ }^{1}$, novitrisnawati@ unesa.ac.id ${ }^{2}$
}

\begin{abstract}
Abstrak
Di tengah pandemi Covid-19 pembelajaran jarak jauh (PJJ) secara daring adalah alternatif pembelajaran yang tepat. Penelitian ini bertujuan untuk mengetahui sejauh mana efektivitas penggunaan Google Classroom sebagai media pembelajaran mata kuliah aplikasi komputer mahasiswa pendidikan administrasi perkantoran Fakultas Ekonomi Universitas Negeri Surabaya. Metode penelitian yang digunakan yaitu kuantitatif deskriptif. Teknik pengumpulan data yang digunakan adalah wawancara dan kuesioner yang disebarkan melalui Google Form kepada 55 mahasiswa aktif angkatan 2019 pendidikan administrasi perkantoran Fakultas Ekonomi Universitas Negeri Surabaya. Hasil penelitian memperoleh rata - rata sebesar 85,49 \% dengan kategori sangat efektif yang membuktikan bahwa penggunaan platform Google Classroom sangat efektif sebagai media pembelajaran mata kuliah aplikasi komputer mahasiswa pendidikan administrasi perkantoran Fakultas Ekonomi Universitas Negeri Surabaya. Indikator mutu pengajaran sangat efektif 86.24 $\%$, tingkat pengajaran sangat efektif $87,64 \%$, insentif efektif $80,22 \%$ dan indikator waktu yang menunjukkan hasil tertinggi sebesar 87,85\% dengan kategori sangat efektif. Mahasiswa dapat mempelajari kembali materi pada Google Classroom kapanpun sehingga mahasiswa lebih memahami materi pembelajaran dan kemudahan mahasiswa dalam menyelesaikan serta mengirim penugasan yang diberikan oleh dosen dengan hasil (nilai) yang baik dengan tepat waktu menunjukkan paltform Google Classroom sangat efektif digunakan sebagai media pembelajaran pada mata kuliah yang mengkombinasikan antara materi dan praktik.
\end{abstract}

Kata Kunci: Pembelajaran Online, Google Classroom, Pembelajaran Efektif.

\begin{abstract}
During the COVID-19 pandemic, distance education which involves online learning or e-Learning became the most suitable learning method. This study aims to examine how effective Google Classroom is as an e-Learning platform for computer application classes in the Department of Office Administration, Faculty of Economics State University of Surabaya. The method that is used in the study is descriptive quantitative. The data obtained through an interview and questionnaire using Google Form from 55 students from the Department of Office Administration of batch 2019, Faculty of Economics State University of Surabaya.The findings show that Google Classroom is an effective platform for computer application classes in the Department of Office Administration, Faculty of Economics State University of Surabaya. It is supported by the average numbers or mean of $85,49 \%$ in the effective category. The teaching quality indicator is effective by $86,24 \%$, the level of teaching is effective by $87,64 \%$, the incentive is effective by $80,22 \%$ and the time indicator that shows the highest result is effective by $87,85 \%$. Students can re-learn materials that have been uploaded on Google Classroom at any time so that students can understand more about learning materials and is also evidenced by the ease with which students complete assignments and assignments given by lecturers with good results (grades) on time show effectiviness of using Google Classroom as a learning media.
\end{abstract}

Keywords: Online Learning, Google Classroom, Effective Learning.

Copyright (c) 2022 Laili Latifathu Nafsi, Novi Trisnawati

$\triangle$ Corresponding author

Email : laili.17080314087@mhs.unesa.ac.id

DOI : https://doi.org/10.31004/edukatif.v4i1.1722

ISSN 2656-8063 (Media Cetak)

ISSN 2656-8071 (Media Online)

Edukatif : Jurnal Ilmu Pendidikan Vol 4 No 1 Tahun 2022 p-ISSN 2656-8063 e-ISSN 2656-8071 


\section{PENDAHULUAN}

Pesatnya kemajuan teknologi memungkinkan apa saja dapat terlaksana dengan bantuan media tanpa harus bertatap muka secara langsung atau bertemu. Menteri Pendidikan dan Kebudayaan mengeluarkan surat edaran yang berisikan himbauan untuk melaksanakan pembelajaran jarak-jauh (PJJ) daring (dalam jaringan) dan work from home (bekerja dari rumah) seperti yang telah disebutkan pada Surat Edaran Mendikbud Nomor 2 dan 3 Tahun 2020 mengenai pencegahan corona virus disease (Covid-19) untuk wilayah terdampak virus Covid-19 guna pencegahan penyebaran virus Covid-19 yang sedang terjadi. E-Learning adalah sebutan populer pembelajaran daring berbasis internet. Menurut Hakim (2016) E-learning merupakan bentuk dari konsep pembelajaran jarak jauh yang dikembangkan menggunakan media digital. M. A. P. Burac (2019) berpendapat bahwa E-Learning dirancang untuk memudahkan kegiatan pembelajaran menggunakan jaringan elektronik sehingga pembelajaran dapat berlangsung secara efektif dan efisien.

Platform Google Classroom berkontribusi pada dunia pendidikan sebagai media untuk menjembatani kegiatan mendistribusikan, mengumpulkan, memberikan penilaian dan feedback pada tugas maupun materi yang diberikan oleh pengajar dengan mudah, kapan dan dimana saja asalkan memiliki jaringan internet. Tujuan utama dirilisnya plafform Google Classroom oleh Google Apps for Education adalah untuk memudahkan komunikasi khususnya interaksi berbagi file antara dosen dengan mahasiswa pada saat proses pembelajaran.

Univeritas Negeri Surabaya adalah lembaga pendidikan perguruan tinggi formal yang telah melaksanakan sistem pembelajaran jarak jauh (daring) guna merealisasikan isi surat edaran Mendikbud No 2 dan 3 tahun 2020 guna pencegahan penularan Covid-19. Menurut hasil wawancara peneliti mahasiswa Fakultas Ekonomi Universitas Negeri Surabaya khususnya mahasiswa Program Studi Pendidikan Administrasi Perkantoran Angkatan 2019 telah melaksanakan kegiatan perkuliahan secara daring. Beberapa platform media pembelajaran E-Learning yang digunakan mereka antara lain Whatsapp Group, E-mail, Google Classroom, Video Conference seperti Zoom dan Google Meet, dan V-Learning yang dapat diaskes pada http://vi-learn.unesa.ac.id/ menggunakan username dan password SIAKAD yang dimiliki oleh setiap dosen dan mahasiswa. Pemilihan penggunaan media pembelajaran disesuaiakan dengan kebutuhan mata kuliah yang sedang ditempuh.

Aplikasi komputer adalah salah satu mata kuliah wajib mahasiswa prodi pendidikan administrasi perkantoran. Mata kuliah aplikasi komputer adalah mata kuliah yang mengkombinasikan antara materi dan praktik. Berdasarkan wawancara peneliti dengan dosen pengampu mata kuliah aplikasi komputer, menurut beliau mata kuliah ini penting untuk mahasiswa karena mahasiswa harus memiliki kompetensi dasar mengoperasikan komputer yang nantinya akan menjadi skill oleh lulusan saat ini. Dosen pengampu mata kuliah aplikasi komputer memilih menggunakan Platform Google Classroom sebagai media pembelajarannya karena menurut beliau Platform Google Classroom lebih easy to use dan user friendly jika dibandingkan dengan platform lainnya. Beberapa kompetensi dasar yang harus dikuasai mahasiswa pada mata kuliah aplikasi komputer yakni mampu terampil dalam mengetik, mengoperasikan Microsoft Office Word, Microsoft Excel dan Microaoft Access. Selanjutnya, peneliti melakukan wawancara dengan mahasiswa aktif pendidikan administrasi perkantoran mengenai penggunaan platform Google Clasroom sebagai media pembelajaran pada mata kuliah aplikasi komputer. Mereka berpendapat bahwa penggunaan platform Google Classroom sangat membantu mereka memahami materi mata kuliah khususnya aplikasi komputer.

Efektivitas diartikan sebagai tindakan yang dilakukan siswa untuk mencapai keberhasilan sehingga hasil belajar didapat secara maksimal (Nana Sudjana, 1990:50). Pembelajaran efektif mencakup seluruh tujuan pembelajaran dari segi social, fisik maupun social. Berdasarkan paparan tersebut dapat disimpulkan bahwa efektivitas pembelajaran adalah tolak ukur keberhasilan yang dapat dicapai sesuai pada tujuan yang telah 
ditetapkan dari penerapan suatu media dan model pembelajaran, dimana dalam hal ini pengukuran hasil belajar dilihat dari nilai siswa.

Banyak dari peneliti sebelumnya telah meneliti mengenai praktik kemudahan pengoperasian platform Google Classroom. Tetapi seperti yang telah kita ketahui bahwa saat ini pembelajaran harus dilakukan secara daring (dalam jaringan) sehingga dosen menggunakan platform Google Classroom saat proses pembelajaran berlangsung. Namun meski begitu kegiatan pembelajaran harus tetap terlaksana agar tetap dapat mencapai tujuan yang telah ditetapkan. Sari (2019) menyebutkan bahwa terdapat pengaruh positif ditinjau dari kualitas layanan, kemudahan, dan manfaat platform Google Classroom pada efektivitas pembelajaran. Bute (2020); Okmawati (2020) juga mengungkap bahwa penggunaan platform Google Classroom cukup membantu bahkan sangat efektif memfasilitasi proses kegiatan pembelajaran. Selanjutnya, penggunaan platform Google Classroom cukup efektif untuk meningkatkan hasil belajar siswa (Achmad Imam (2020); Fauzan \& Arifin (2019).

Berdasarkan latar belakang diatas penelitian ini fokus pada salah satu mata kuliah yang mengkombinasikan antara materi dan praktik tetapi menggunakan platform Google Classroom sebagai media pembelajaran pada proses pembelajarannya. Rumusan masalah pada penelitian ini adalah apakah platform Google Classroom efektif digunakan sebagai media pembelajaran mata kuliah aplikasi komputer mahasiswa prodi pendidikan administrasi perkantoran Fakultas Ekonomi Universitas Negeri Surabaya. Penelitian ini bertujuan untuk mengetahui apakah platform Google Classroom efektif digunakan sebagai media pembelajaran pada mata kuliah yang mengkombinasikan antara materi dan praktik bagi mahasiswa prodi pendidikan administrasi perkantoran Fakultas Ekonomi Universitas Negeri Surabaya. Peneliti berharap agar penelitian ini dapat menjadi bahan kajian peneliti lain terkait keefektifan penggunaan Google Classroom sebagai media pembelajaran khususnya pada mata kuliah yang mengkombinasikan antara materi dan praktik. Dan hasil penelitian ini diharapkan dapat menjadi bahan pertimbangan bagi tenaga pengajar saat menentukan media pembelajaran yang akan digunakan.

\section{METODE PENELITIAN}

Metode penelitian pada penelitian ini adalah kuantitaif dengan pendekatan deskriptif. Penelitian kuantitatif adalah penelitian yang didasari oleh filsafat positivisme, berfokus pada fakta objektif yang telah diselidiki dengan cara kuantitatif (Sukmadinata, 2015:53). Selanjutnya yang dimaksud dengan pendekatan deskriptif merupakan penelitian yang memiliki tujuan untuk menganalisis serta memastikan suatu kondisi maupun keadaan yang hasilnya nanti akan dipaparkan dalam bentuk laporan penelitian (Arikunto, 2013). Desain pada penelitian ini adalah angka-angka dan perhitungan statistic. Teknik analisis data penelitian ini menggunakan analisis kuantitatif deskriptif dalam bentuk persentase. Dipilihnya metode kuantitatif pada penelitian ini karena penelitian ini mengukur tingkat keefektifan penggunaan platform Google Classroom sebagai media pembelajaran mata kuliah aplikasi komputer mahasiswa pendidikan administrasi perkantoran Fakultas Ekonomi Universitas Negeri Surabaya dengan scoring rumus berikut ini:

$$
\text { Presentase Penilaian (\%) }=\frac{\sum \text { skor yang di peroleh }}{\sum \text { skor tertinggi }} \times 100 \%
$$

Sumber: Riduwan (2018:41)

Penerapan rumus penskoran pada skor pilihan jawaban kuisioner diadaptasi dari Riduwan (2018:39) poin 5 dengan kriteria jawaban Sangat Setuju (SS), poin 4 dengan kriteria jawaban Setuju (S), poin 3 dengan kriteria jawaban Netral (N), poin 2 dengan kriteria jawaban Tidak Setuju (TS), poin 1 dengan kriteria jawaban Sangat Tidak Setuju (STS). Skor pada jawaban kuisioner digunakan untuk menghitung indikator menilai 
keefektifan pembelajaran. Menurut Slavin (2008:274) terdapat 4 indikator yang dijadikan sebagai instrumen untuk mengukur keefektifan pembelajaran pada kuisioner yang dibagikan kepada mahasiswa aktif prodi pendidikan admnistrasi perkantoan Universitas Negeri Surabaya angkatan 2019 sebagai berikut : (1) Mutu Pengajaran, di lihat dari proses pembelajaran dan hasil pembelajaran di lihat dari nilai. (2) Tingkat Pengajaran, di lihat dari sejauh mana siswa siap mengikuti pembelajaran. (3) Insentif, dapat di lihat dari aktivitas dosen memberikan motivasi kepada mahasiswa. (4) Waktu, dapat di lihat dari mahasiswa di beri cukup banyak waktu untuk mempelajari bahan yang diajarkan.

Mahasiswa prodi pendidikan administrasi perkantoran angkatan 2019 Fakultas Ekonomi Universitas Negeri Surabaya adalah populasi pada penelitain ini. Kuisoner dibagikan kepada mahasiswa aktif prodi pendidikan administrasi perkantoran angkatan 2019 kelas a, b dan I. Arikunto (2010) dalam penelitiannya menyebutkan bahwa penelitian yang mengambil subjek sampel kurang dari 100 maka semuanya dapat dijadikan sampel. Beberapa tahapan metode pengumpulan data pada penelitian ini adalah: (1) Peneliti melakukan wawancara dengan dosen pengampu mata kuliah aplikasi komputer Fakultas Ekonomi Universitas Negeri Surabaya dan mahasiswa aktif prodi pendidikan administrasi perkantoran angkatan 2019. Memperoleh informasi secara langsung dari sumbernya merupakan teknik pengumpulan data dengan wawancara (Riduwan, 2018:56); (2) Kuisioner, Penyebaran kuisioner dilakukan via online menggunakan Google Form melalui pesan WhatsApp kepada mahasiswa aktif prodi pendidikan administrasi perkantoran angkatan 2019 Fakultas Ekonomi Universitas Negeri Surabaya. Kuisioner adalah daftar pertanyaan untuk responden yang telah bersedia memberikan tanggapan sesuai dengan yang diminta pengguna. (Riduwan, 2018:52); (3) Dokumentasi terdiri dari foto pembelajaran melalui google classroom dan nilai mahasiswa. Adapun tahapan metode analisis data kuantitatif dimana data yang dihasilkan nantinya berupa angka - angka (Sukmadinata, 2015:53) pada penelitin ini terdapat 3 (Tiga) tahap yaitu: (1) Pengolahan data, dimana data yang telah diperoleh secara keseluruhan diteliti kembali kelengkapannya. (2) Pengorganisasian data, meliputi menginput dan memasukkan data yang telah diperiksa pada tabel frekuensi, kemudian melakukan perhitungan denga cara menjumlah skor pada setiap pertanyaan, selanjutnya peneliti membuat kelas interval kemudian menjumlah skor dari jawaban setiap responden. (3) Penemuan hasil, hasil diperolehan dari perhitungan semua skor setiap indikator yang kemudian dipaparkan dalam persentase, selanjutnya hasil persentase dikelompokkan sesuai dengan kelas intervalnya. Angka - angka tersebut selanjutnya akan dideskripsikan dalam bentuk kalimat agar lebih mudah dipahami.

Setelah data dianalisis secara kuantitatif, data di rata-rata dan selanjutnya akan dikalompokkan sesuai kriteria penilaian skala likert berikut:

Tabel 1. Kriteria Intepretasi Skror Keefektifan Penggunaan Platform Google Classroom

\begin{tabular}{c|c}
\hline Penilaian & Kriteria Keefektifan \\
\hline $0 \%-20 \%$ & Sangat Tidak Efektif \\
\hline $21 \%-40 \%$ & Tidak Efektif \\
\hline $41 \%-60 \%$ & Cukup Efektif \\
\hline $61 \%-80 \%$ & Efektif \\
\hline $81 \%-100 \%$ & Sangat Efektif \\
\hline
\end{tabular}

\section{HASIL DAN PEMBAHASAN}

Hasil analisis data setelah peneliti menyebarkan kuisioner menggunakan Google Form melalui WhatsApp, yang kemudian ditanggapi oleh responden sejumlah 55 mahasiswa aktif prodi pendidikan administrasi perkantoran angkatan 2019 Fakultas Ekonomi Universitas Negeri Surabaya. Berdasarkan dari 4 
(empat) indikator yang digunakan sebagai tolak ukur penilaian menunjukkan hasil persentase sebesar 85,49 dengan kategori sangat efektif membuktikan bahwa penggunaan platform Google Classroom sangat efektif sebagai media pembelajaran mata kuliah aplikasi komputer mahasiwa pendidikan administrasi perkantoran Fakultas Ekonomi Universitas Negeri Surabaya. Secara keseluruhan hasil kefektifan penggunaan latform Google Classroom sebagai media pembelajaran mata kuliah aplikasi computer dapat dilihat pada tabel berikut:

Tabel 2. Distribusi Keefektifan Penggunaan Platform Google Classroom

\begin{tabular}{|c|c|c|c|}
\hline Indikator & Pertanyaan & Persentase & Hasil \\
\hline \multirow[t]{11}{*}{ Mutu Pengajaran } & $\begin{array}{l}\text { 1. Platform Google Classroom dapat } \\
\text { diakses dengan mudah. }\end{array}$ & $93.45 \%$ & Sangat Efektif \\
\hline & $\begin{array}{l}\text { 2. Materi yang disajikan melalui } \\
\text { platform Google Classroom sesuai } \\
\text { dengan materi perkuliahan mata } \\
\text { kuliah aplikasi computer. }\end{array}$ & $88,73 \%$ & Sangat Efektif \\
\hline & $\begin{array}{l}\text { 3. Penggunaan platform Google } \\
\text { Classroom dapat mempermudah saya } \\
\text { dalam mengirimkan tugas mata kuliah } \\
\text { aplikasi computer. }\end{array}$ & $89,09 \%$ & Sangat Efektif \\
\hline & $\begin{array}{l}\text { 4. Dosen memberikan kesempatan kepada } \\
\text { mahasiswa untuk bertanya dan } \\
\text { berdiskusi saat pembelajaran }\end{array}$ & $85,82 \%$ & Sangat Efektif \\
\hline & $\begin{array}{l}\text { 5. Dosen memberikan respon terhadap } \\
\text { pertanyaan yang muncul saat proses } \\
\text { pembelajaran berlangsung. }\end{array}$ & $83,27 \%$ & Sangat Efektif \\
\hline & $\begin{array}{l}\text { 6. Dosen selalu menemani } \\
\text { pembelajaran berlangusng } \\
\text { selesai. }\end{array}$ & $81,45 \%$ & Sangat Efektif \\
\hline & $\begin{array}{l}\text { 7. Dosen menjelaskan arah dan tujuan } \\
\text { pembelajaran saat menggunaan } \\
\text { platform Google Classroom }\end{array}$ & $85,45 \%$ & Sangat Efektif \\
\hline & $\begin{array}{l}\text { 8. Saya dapat mengikuti kegiatan } \\
\text { pembelajaran menggunakan platform } \\
\text { Google Classroom dengan baik. }\end{array}$ & $88,73 \%$ & Sangat Efektif \\
\hline & $\begin{array}{l}\text { 9. Mudah mempraktikkan ketrampilan } \\
\text { mengetik setelah memahami materi } \\
\text { pada PPT dan mengamati video } \\
\text { tutorial praktik mengetik yang } \\
\text { dibagikan melalui platform Google } \\
\text { Classroom }\end{array}$ & $86,55 \%$ & Sangat Efektif \\
\hline & $\begin{array}{l}\text { 10. Mudah mengoperasikan Microsoft } \\
\text { Office Word setelah memahami materi } \\
\text { pada PPT dan mengamati video } \\
\text { tutorial pengoperasian Microsoft } \\
\text { Office Word yang dibagikan melalui } \\
\text { platform Google Classroom }\end{array}$ & $86,55 \%$ & Sangat Efektif \\
\hline & $\begin{array}{l}\text { 11. Mudah mengoperasikan Microsoft } \\
\text { Excel setelah memahami materi pada } \\
\text { PPT dan mengamati video tutorial }\end{array}$ & $85,82 \%$ & Sangat Efektif \\
\hline
\end{tabular}




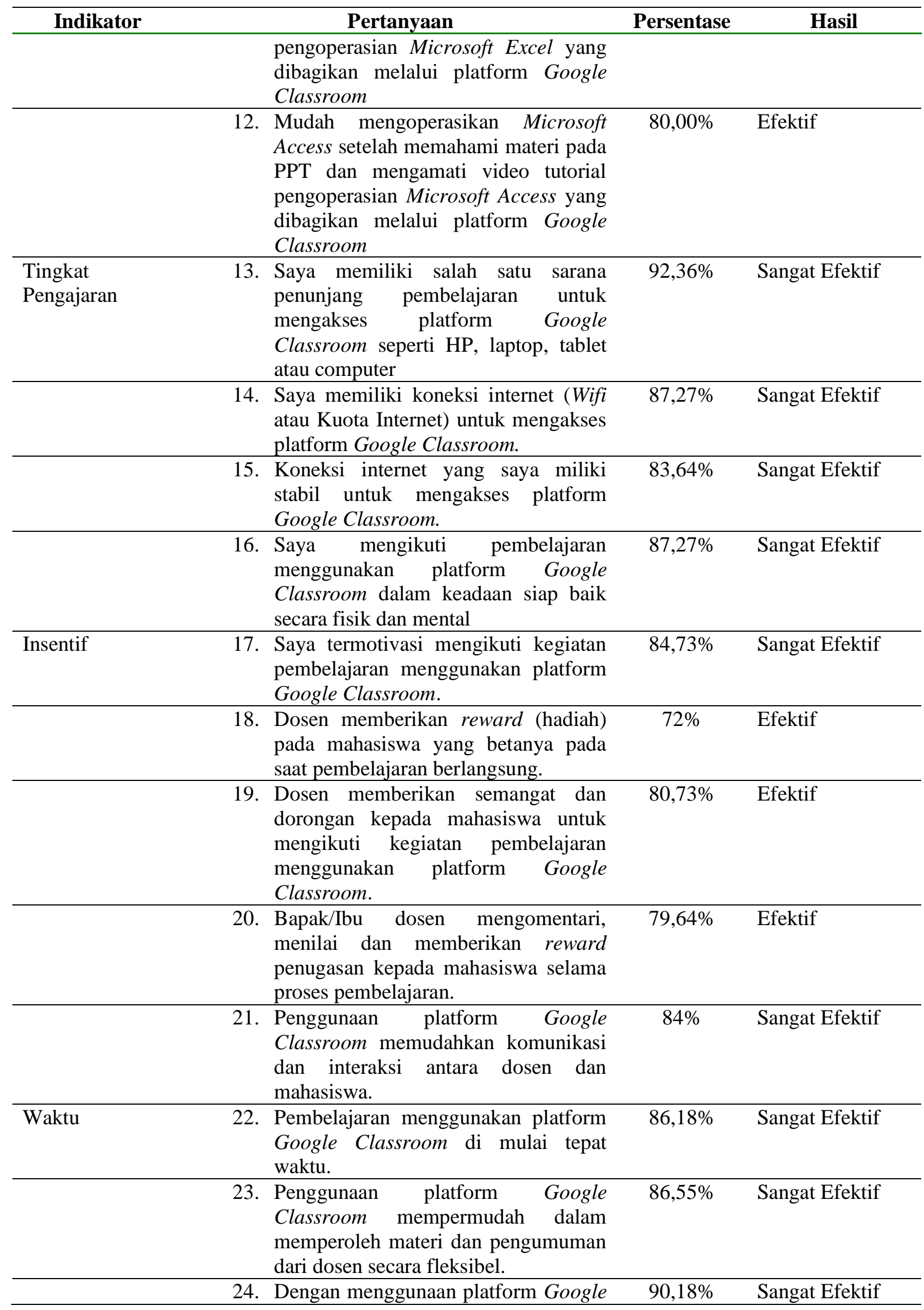


DOI: https://doi.org/10.31004/edukatif.v4i1.1722

\begin{tabular}{|c|c|c|c|}
\hline Indikator & Pertanyaan & Persentase & Hasil \\
\hline & $\begin{array}{l}\text { Classroom saya bisa mempelajari } \\
\text { kembali apapun. }\end{array}$ & & \\
\hline & $\begin{array}{l}\text { 25. Saya dapat menyelesaikan tugas } \\
\text { dengan tepat waktu. }\end{array}$ & $90,18 \%$ & Sangat Efektif \\
\hline & $\begin{array}{l}\text { 26. Berakhirnya pembelajaran } \\
\text { menggunakan platform Google } \\
\text { Classroom sesui dengan jadwal. }\end{array}$ & $86,18 \%$ & Sangat Efektif \\
\hline
\end{tabular}

Sumber : Diolah oleh peneliti (2021)

Tabel 3. Intepretasi Kriteria Keefektifan Penggunaan Google Classroom

\begin{tabular}{ccc}
\hline Indikator & Persen & Kategori \\
\hline Mutu Pengajaran & $86,24 \%$ & Sangat Efektif \\
\hline Tingkat Pengajaran & $87,64 \%$ & Sangat Efektif \\
\hline Insentif & $80,22 \%$ & Efektif \\
\hline Waktu & $87,85 \%$ & Sangat Efektif \\
\hline Rata-Rata & $85.49 \%$ & Sangat Efektif \\
\hline & & Sumber: Diolah oleh peneliti (2021)
\end{tabular}

\section{Indikator Mutu Pengajaran}

Pada indikator mutu pengajaran terdapat 12 item pertanyaan memperoleh hasil persentase $86,24 \%$ dengan kategoti sangat efektif. Point pertanyaan pertama mengenai kemudahan mahasiswa prodi pendidikan administrasi perkantoran mengakses platform Google classroom mendapatkan hasil persentase 93,45\% dengan kategori sangat efektif. Hal tersebut karena Google Classroom memiliki tampilan simpel sehingga mudah dipahami pengguna. Mahasiswa merasa sangat terbantu dalam pembelajaran mata kuliah aplikasi komputer secara daring dengan menggunakan platform Google Classroom sebagai media pembelajaran. Sedangkan untuk dosen, dosen memberikan umpan balik berupa komentar atau nilai dari tugas yang diberikan secara langsung kepada mahasiswa sehingga hal tersebut menarik perhatian mahasiswa. Sejalan dengan penelitian Utami (2019) terdapat 82,4\% mahasiswa setuju bahwa platform Google Classroom mudah diakses sehingga mahasiswa tertarik untuk menggunakan platform Google Classroom.

Kesesuaian materi yang di sampaikan dosen dengan materi perkuliahan RPS mata kuliah aplikasi computer menunjukkan hasil $88,73 \%$ dengan kategori sangat efektif. Materi dan soal soal yang dibagikan dosen melalui platform Google Classroom untuk mahasiswa sesuai dengan materi perkuliahan. Hasil tersebut didukung oleh pernyataan wawancara pada mahasiswa bahwa materi dan penugasan yang diupload oleh dosen selama ini telah sesuai dengan RPS mata kuliah yang terdapat pada SIAKAD UNESA. Sabran \& Sabara (2019) menyebutkan aspek perancangan dan pembuatan materi menggunakan platform Google Classroom masuk dalam kaetgori cukup efektif dengan persentase tingkat kecenderungan sebesar 75,14\%.

Kemudahan mahasiswa dalam mengirim tugas pembelajaran mata kuliah aplikasi komputer menggunakan platform Google Classroom menunjukkan hasil persentase $89.09 \%$ dengan kategori sangat efektif. Bagi mahasiswa prodi pendidikan administrasi perkantoran platform Google Classroom memudahkan mereka mengirimkan tugas khususnya pada mata kuliah aplikasi komputer karena platform Google Classroom secara otomatis sinkron dengan aplikasi Google Document, Gmail dan Google Drive. Pernytaaaan tersebut didukung penelitian Brock (2015) yang menyebutkan bahwa salah satu dari beberapa manfaat dari platform Google Classroom adalah secara otomatis platform Google Classroom sinkron dengan aplikasi yang biasa mahasiswa gunakan yaitu Google Document, Calender, Gmail, Google Drive dan Google Formulir.

Dosen memberikan waktu dan kesempatan kepada mahasiswanya bertanya dan berdiskusi pada saat proses pembelajaran menggunakan platform Google Classroom berlangsung menunjukkan hasil 85,82\% 
dengan kategori sangat efektif. Untuk aktivitas bertanya dan berdiskusi dosen memberikan kesempatan tersebut setelah materi dan tugas dibagikan melalui platform Google Classrrom sampai pada batas waktu pengumpulan tugas berakhir. Pada rentang waktu tersebut mahasiswa dapat bertanya kepada dosen melalui fitur announcements dan kolom komentar. Hasil tersebut didukung dengan pernyataan wawancara pada mahasiswa bahwa saat proses pembelajaran mereka memanfaatkan fitur kolom komentar bahkan mereka melakukan absesnsi melalui kolom komentar. Biasanya setelah mengupload materi dan memberikan penugasan dosen menanyai mahasiswa apakah ada yang kurang jelas dan ditanyak an melalui kolom komentar. Hal tersebut didukung oleh penelitian دى ال مج ع بد, (2020) yang menyatakan bahwa Google Classroom membantu kegiatan berdiskusi secara online saat kegiatan belajar mengajar.

Dosen memberikan respon (feedback) pada pertanyaan yang muncul saat pembelajaran berlangsung menggunakan platform Google Classroom menunjukkan hasil 83,27\% dengan kategori sangat efektif. Dosen menjawab pertanyaan mahasiswa melalui fitur announcements ataupun pada kolom komentar. Hasil tersebut sejalan dengan hasil penelitian K.Y.S. Putri (2020) dimana Platform Google Classroom dinyatakan efektif sebagai media komunikasi ditinjau dari 6 indikator efektivitas komunikasi seperti ketepatan penerima pesan, isi pesan, media komunikasi, format pesan, sumber pesan, dan ketepatan waktu.

Dosen selalu menemani saat pembelajaran berlangsung menggunakan platform Google Classroom hingga selesai menunjukkan hasil 81,45\% dengan kategori sangat efektif. Dari hasil analisis data tersebut, dosen pengampu mata kuliah aplikasi komputer seringkali sering kali mendampingi mahasiswa saat pembelajaran berlangsung. Hasil tersebut didukung pernyataan mahasiswa bahwa dosen dengan cepat menagnggapi pertanyaan yang ditanyakan melalui kolom komentar. Pernyataan tersebut didukung penelitian Brock (2015) yang meyebutkan beberapa manfaat dari Google Classroom salah satunya adalah dosen dapat menambahkan (mengundang) asisten dosen. Dengan begitu jika dosen sedang berhalangan mengajar, asisten dosen dapat menggatikan dosen untuk mengajar.

Dosen menjelaskan arah dan tujuan pembelajaran saat menggunaan platform Google Classroom menunjukkan hasil $85,45 \%$ pada kategori sangat efektif. Hasil tersebut menunjukkan bahwa dosen mata kuliah aplikasi komputer dari awal pembelajaran dimulainya perkuliahan mata kuliah aplikasi komputer telah menjelaskan arah dan tujuan pembelajaran mata kuliah wajib tersebut. Hasil tersebut didukung pernyaataan wawancara pada mahasiswa dimana pada saat melakukan kesepakatan kontrak perkuliahan dosen juga menjelaskan secara garis besar mengenai materi apa saja dan tujuan pembelajaran mata kuliah aplikasi komputer. Sabran \& Sabara (2019) menyebutkan bahwa aspek perencanaan pembelajaran pada google classroom termasuk dalam kategori cukup efektif dengan persentase tingkat kecenderungan sebesar 77,57\%.

Mahasiswa dapat mengikuti pembelajaran menggunakan platform Google Classroom dengan baik menunjukkan hasil $88,73 \%$ pada kategori sangat efektif. Berdasarkan hasil tersebut menunjukkan bahwa mahasiswa prodi pendidikan administrasi perkantoran dapat mengikuti pembelajaran mata kuliah aplikasi komputer dengan baik, hal tersebut juga di buktikan dari nilai mahasiswa pada mata kuliah aplikasi komputer yang secara keseluruhan sudah baik. 91,7 \% siswa memperoleh nilai pembelajaran baik dengan menggunakan platform google classroom sebagai media pembelajaran karena platform google classroom mudah digunakan kapan saja sehingga memudahkan mendapatkan materi (Heggart \& Yoo, 2018).

Mahasiswa mudah mempraktikkan ketrampilan mengetik setelah memahami materi pada PPT dan mengamati video tutorial mengetik praktik mengetik yang dibagikan melalui platform Google Classroom menunjukkan hasil $86,55 \%$ dengan kategori sangat efektif. Berdasarkan hasil persentase tersebut menunjukkan kemudahan mahasiswa prodi pendidikan administrasi perkantoran dalam melakukan praktik ketrampilan mengetik yang merupakan salah satu indikator dasar pencapaian pada mata kuliah aplikasi komputer menunjukkan hasil yang baik. Mahasiswa dapat berulang kali memutar video tutorial mengetik kapanpun saat mereka berlatih mengetik. Pendapat tersebut didukung oleh penelitian Okmawati (2020) yang juga menyatakan bahwa penggunaan Google Classroom selama pandemi efektif dan bermanfaat untuk 
meningkatkan keterampilan, kedisiplinan siswa, serta memenuhi tuntutan pemerintah untuk terus melanjutkan proses belajar mengajar. Materi mengetik ini bertujuan untuk menumbuhkan, mengembangkan dan melatih ketrampilan megetik cepat menggunakan 10 jari bagi mahasiswa.

Mahasiswa mudah mengoperasikan Microsoft office word setelah memahami materi pada PPT dan mengamati video tutorial pengoperasian Microsoft office word yang dibagikan melalui platform Google Classroom menunjukkan hasil 86,55\% dengan kategori sangat efektif. Berdasarkan persentase tersebut menunjukkan mahasiswa prodi pendidikan administrasi perkantoran mudah dalam mempraktikkan pengoperasian Microsoft office word karena seperti yang telah kita ketahui bahwa platform Google Classroom bagian dari Google Suite for Education secara langsung terhubung dengan beberapa platform education lainnya, salah satunya adalah Google Office yang terdiri dari Slide, Docs dan Spreadsheet. Pernyataan tersebut didukung oleh penelitian Brock (2015) menyebutkan bahwa salah satu dari beberapa manfaat Platform Google Classrom adalah secara otomatis terhubung dengan Google Drive, Google Document, Gmail, Formulir dan Calendar yang biasa digunakan oleh mahasiswa. Setelah mempelajari materi Microsoft office word mahasiswa menjadi lebih memahami fungsi utama dari menu utama pada Microsoft office word, cara memberikan halaman pada dokumen dengan cepat, dan membuat daftar pustaka otomatis pada Microsoft office word.

Mahasiswa mudah mengoperasikan Microsoft excel setelah memahami materi pada PPT dan mengamati video tutorial pengoperasian Microsoft Excel yang dibagikan melalui platform Google Classroom menunjukkan hasil $85,82 \%$ dengan kategori sangat efektif. Berdasarkan hasil persentase tersebut menunjukkan mahasiswa prodi pendidikan administrasi perkantoran dengan menggunakan platform Google Classrrom memudahkan mereka memahami materi mengenai praktik Microsoft excel melalui penjelasan video tutorial yang dibagikan oleh dosen menggunakan platform Google Classroom. Hal tersebut juga dibuktikan dengan nilai akhir mata kuliah aplikasi komputer mahasiswa prodi pendidikan administrasi perkantoran secara keseluruhan sudah baik. Jannatu et al., (2015) dalam penelitiannya menyatakan hasil belajar siswa dapat meningkat dengan melatih memberikan pembelajaran berbasis proyek kepada siswa melalui daring. Setelah mempelajari materi Microsoft excel mahasiswa memahami fungsi dari Worksheet dan Workbook, dan penggunaan rumus serta fungsi di Microsoft excel.

Mahasiswa mudah mengoperasikan Microsoft acess setelah memahami materi pada PPT dan mengamati video tutorial pengoperasian Microsoft acess yang dibagikan oleh dosen menggunakan platform Google Classroom menunjukkan hasil $80 \%$ dengan kategori efektif. Berdasarkan hasil persentase tersebut menunjukkan bahwa mahasiswa prodi pendidikan administrasi perkantoran mudah memahami materi pengoperasian Microsoft acess. Platform Google Classroom memungkinkan mahasiswa untuk lebih memahami materi yang telah dibagikan oleh dosen. Rohaeti (2020) dalam penelitiannya menyatakan bahwa pembelajaran secara daring menggunakan platform Google Classroom selama pandemi Covid-19 menunjukkan respon yang baik karena $>50 \%$ merespon positif. Setelah mempelajari materi Microsoft acess mahasiswa dapat mengoperasikan database pada Microsoft acess.

\section{Tingkat Pengajaran}

Indikator kedua adalah tingkat pengajaran menunjukkan hasil 87,64\% dengan kategori sangat efektif. Indikator tingkat pengajaran dilihat dari sisi ketersediaan sarana, koneksi internet serta stabilnya kondisi sinyal internet untuk mendukung pembelajaran mata kuliah aplikasi komputer menggunakan platform Google Classroom. Point pertama dilihat dari sarana penunjang pembelajaran untuk mengoperasikan platform Google Classroom menunjukkan hasil 92,36\% dengan kategori sangat efektif. Dimana dalam hal ini berdasarkan penelitian mahasiswa memiliki minimal salah satu sarana penunjang pembelajaran seperti HP, Laptop, tablet atau komputer. Pada point ini sebagian besar mahasiswa memiliki hp dan laptop untuk mengakses Google Classrroom. Chan et al., (2015); Gikas \& Grant, (2013); Kay \& Lauricella, (2011) dalam penelitiannya 
menyebutkan penggunaan laptop dan smartphone oleh mahasiswa dalam mengakses internet yang tidak terbatas ruang dan waktu mendukung mahasiswa mengikuti pembelajaran daring sehingga memungkinkan mahasiswa berinteraksi dan berkomunikasi dengan bantuan koneksi internet.

Mahasiswa memiliki salah satu jenis koneksi internet (Wifi atau Kuota internet) untuk mengoperasikan platform Google Classroom menunjukkan hasil 87,27\% dengan kategori sangat efektif. Persentase tersebut menunjukkan sebagian besar mahasiswa memiliki jenis koneksi internet (Wifi atau Kuota internet) untuk mengikuti mata kuliah aplikasi komputer menggunakan platform Google Classroom. Selain mahasiswa mempunyai wifi atau kuota internet pribadi, mahasiswa setiap bulan mendapatkan kuota gratis dari KEMENDIKBUD sebanyak 15 GB untuk digunakan pembelajaran daring. Penggunaan kuota intenet pada perkuliahan daring lebih fleksibel kapan pun dan di manapun sedangkan untuk penggunaan wifi mahasiswa harus berada di area jangkauan wifi yang menyebabkan aktivitasnya lebih terbatas (Widiyono, 2020).

Kondisi sinyal internet yang stabil untuk mengikuti pembelajaran daring menunjukkan 83,64\% dengan kategori sangat efektif. Persentase tersebut menunjukkan kestabilan jaringan internet yang dimiliki mahasiswa untuk mengikuti mata kuliah aplikasi komputer menggunakan platform Google Classroom sangat baik. Pengoperasian platform Google Classroom yang tidak membutuhkan banyak kuota memungkinkan proses pembelajaran berjalan lancar. Platform Google Classroom yang mudah digunakan memudahkan mahasiswa mengkases dengan cepat tanpa membutuhkan banyak kuota, seperti yang telah kita ketahui bahwa platform Google Classroom memang tidak membutuhkan banyak kuota dalam penggunaannya (Destyana \& Surjanti, 2021).

Mahasiswa mengikuti kelas mata kuliah aplikasi komputer menggunakan platform Google Classroom dalam keadaan siap secara fisik maupun mental menunjukkan hasil 87,27\% dengan kategori sangat efektif. Hasil tersebut menunjukkan bahwa mahasiswa selalu siap secara fisik dan mental dalam mengikuti kelas aplikasi komputer. Mahasiswa berpendapat bahwa pembelajaran yang dilkukan secara daring membutuhkan lebih sedikit energi meski tetap membutuhkan kuota yang bisa disebut banyak. Pendapat tersebut sejalan dengan penelitian Gunawan \& Sunarman (2017) yang juga menyebutkan bahwa belajar menggunakan platform Google Classroom tidak membutuhkan banyak energi sehingga mahasiswa tidak merasa lelah saat proses pembelajaran jika dibandingkan dengan pembelajaran secara konvensional dimana mahasiswa membutuhkan banyak energi yang digunakan untuk mencatat hal-hal penting, sehingga mahasiswa berpandangan dengan menggunakan platform Google Classroom maka pembelajaran dapat lebih efektif (Gunawan \& Sunarman, 2017).

\section{Insentif}

Indikator selanjutnya adalah indikator insentif yang menunjukkan hasil 80,22\% dengan kategori efektif. Keefektikan indikator insentif pada point pertama penelitian ini dilihat dari kegiatan dosen memberikan motivasi kepada mahasiswa untuk mengikuti kelas aplikasi komputer menggunakan platform Google Classroom. Dalam hal ini dosen selalu memberikan motivasi kepada mahasiswa menunjukkan hasil 84,73\% dengan kategori sangat efektif. Sejak awal pertemuan kelas pertama kali saat membuat kesepakatan kontrak perkuliahan mahasiswa dan dosen berdiskusi mengenai platform apa yang memudahkan mereka dalam mengampu mata kuliah aplikasi komputer sehingga mahasiswa termotivasi mengikuti pembelajaran. Oleh karena itu pada indikator ini mendapatkan hasil efektif dimana mahasiswa memahami pembelajaran sehingga mereka ikut serta terlibat aktif saat pembelajaran. Mahasiswa akan lebih lebih terlibat dalam pembelajaran karena siswa termotivasi ketika melaksanakan e-learning dan jika siswa berhasil memahami pembelajaran maka mereka akan lebih mudah untuk mencapai tujuan pembelajaran (Harandi, 2015; Kim \& Frick, 2011).

Dosen memberikan hadiah (reward) pada mahasiswa yang aktif bertanya kepada guru saat pembelajaran daring berlangsung menunjukkan hasil $72 \%$ dengan kategori efektif. Hasil tersebut menunjukkan bahwa kegiatan dosen memberikan reward berupa tambahan nilai plus pada kaetogori keaktifan 
pada mahasiswa sebagai bentuk penghargaan kepada mahasiswa yang aktif bertanya, berpendapat ataupun memberikan sanggahan pada saat pembelajaran sesuai dengan kontrak mata kuliah aplikasi komputer sejak pertemuan pertama aplikasi komputer menggunakan platform Google Classroom. Pada indikator ini mahasiswa bertanya kepada dosen mengenai sudut pandang mereka mengenai suatu materi, memberikan tanggapan serta sanggahan pada saat temannya sedang meakukan prsesentasi ataupun membantu menjawab pertanyaan kelompok atau temannya yang lain. Berdasarkan hasil penelitian cukup baik karena memang terdapat hubungan antara motivasi dengan memberikan reward berpengaruh pada hasil belajar mahasiswa. Hasil penelitian Salamor (2017) menunjukkan bahwa pemberian motivasi berprestasi dan hadiah (reward) kepada siswa menunjukkan hubungan dan hasil positif.

Dosen memberikan semangat dan dorongan kepada mahasiswa mengikuti pembelajaran aplikasi komputer menunjukkan hasil 80,73\% dengan kategori efektif. Hasil tersebut menunjukkan bahwa kegiatan dosen memberikan semangat dan dorongan kepada mahasiswa untuk mengikuti kelas mata kuliah aplikasi komputer menggunakan platform Google Classroom sudah baik. Pada indikator ini dosen mata kuliah aplikasi komputer memberikan semangat dan dorongan kepada mahasiswa dengan cara memberikan gambaran secara luas dan penjelasan mengapa mata kuliah aplikasi kompuetr wajib ditempuh mahasiswa, dosen memberikan penjelasan bahwa skill mengoperasikan komputer adalah skill yang harus dimiliki lulusan saat ini. Sejalan dengan penelitian Manizar (2017) menyatakan bahwa optimalnya hasil belajar dipengaruhi oleh adanya motivasi, karena motivasi berfungsi sebagai pendorong mahasiswa agar semangat belajar, menyeleksi perbuatan mereka, menentukan arah perbuatan, serta sebagai pendorong usaha siswa untuk pencapaian prestasi.

Dosen mengomentari, menilai dan memberikan reward penugasan kepada mahasiswa selama proses pembelajaran menunjukkan hasil $79,64 \%$ dengan kategori efektif. Hasil tersebut menunjukkan bahwa mahasiswa pada saat pembelajaran mata kuliah aplikasi komputer menggunakan platform Google Classroom mendapatkan feedback dari dosen. Pada indikator ini dosen biasanya memberikan komentar dan mereview (membahas) penugasan pada pertemuan selanjutnya, sehingga pada saat mereview penugasan mahasiswa yang memiliki sudut pandang berbeda ataupun memiliki sanggahan dapat disampaikan. Dengan begitu meski pembelajaran dilakukan secara daring namun tetap dapat menumbuhkan rasa percaya diri pada mahasiswa. (Ali \& Hamidah, 2020) dalam penelitiannya menyatakan bahwa pembelajaran secara daring membuat mahasiswa lebih berani untuk bertanya, berinteraksi dan berekspresi serta mengutarakan idenya secara bebas karena pembelajaran yang dilakukan secara daring dapat menghilangkan rasa malu pada diri mahasiswa.

Penggunaan platform Google Classroom memudahkan komunikasi dan interaksi antara dosen dan mahasiswa menunjukkan hasil $84 \%$ dengan kategori sangat efektif. Hasil tersebut menunjukkan bahwa mahasiswa mudah berinteraksi dan berkomunikasi dengan dosen melalui platform Google Classroom. Pada indikator ini dosen dan mahasiswa dapat berkomomunikasi dengan mudah. Mahasiswa dapat langsung bertanya melalui kolom komentar sedangkan dosen yang mendapatkan notifikasi juga secara langsung bisa menjawab pertanyaan mahasiswa melalui kolom komentar. Oleh karena itu dosen dapat dengan cepat memberikan feedback kepada mahasiswa. Melalui kolom komentar, dosen dapat memberikan masukan ataupun menjawab pertanyaan mahasiswa sehingga memudahkan terjadinya komunikasi dua arah dan interaksi antara mahasiswa serta dosen (Rohaeti, 2020).

\section{Waktu}

Perolehan persentase pada indikator waktu menunjukkan hasil tertinggi diantara 4 (empat) indikator lain yang digunakan untuk menilai keefektifan pembelajaran. Indikator waktu menunjukkan hasil sebesar 87,85\% dengan kategori sangat efektif. Indikator waktu di lihat dari ketepatan waktu dimulai dan berakhirnya pembelajaran, mahasiswa mendapatkan materi dan pengumuman secara fleksibel, mahasiswa dapat 
menyelesaikan tugas dengan tepat waktu serta dapat mempelajari kembali materi kapanpun berdasarkan hasil penelitian sangat baik, sehingga memperoleh skor persentase tertinggi yang berkategori sangat efektif.

Indikator waktu yang dipertama dilihat dari ketepatan waktu dimulainya pembelajaran yang menunjukkan hasil $86,18 \%$ dengan kategori sangat efektif. Mahasiswa mengakui bahwa menggunakan platform Google Classroom pembelajaran dapat lebih disiplin sesui jadwal perkuliahan yang ditelah ditetapkan kampus. Dalam hal ini mahasiswa biasanya diberi waktu 15 menit untuk absn pada kolom komentar.jadwal pembelajaran meski pembelajaran dilakukan secara daring pembelajaran disesuaikan dengan jadwal yang telah ditetapkan oleh kampus. Hal tersebut sejalan dengan penelitian Muhardi \& Ponidi (2020) menyatakan bahwa penyusunan dan pembuatan jadwal pelajaran ditengah pandemi covid-19 dilakukan oleh masing-masing sekolah untuk menyinkronkan atau menyesuaikan dengan pembelajaran daring yang akan di laksanakan.

Platform Google Classroom memudahkan mahasiswa mendapatkan materi juga pegumuman secara fleksibel dari dosen menunjukkan hasil $86,55 \%$ dengan kategori sangat efektif. Persentase tersebut menunjukkan mahasiswa sangat terbantu dalam memperoleh materi maupun pengumuman oleh dosen melalui platform Google Classroom pada mata kuliah aplikasi komputer. Dengan menggunakan platform Google Classroom proses pembelajaran menjadi lebih efektif karena dosen dan mahasiswa dapat bertatap muka kapan saja melalui kelas daring Google Classroom (Henukh et al., 2020). Selain itu pendapat tersebut didukung penelitian Abid Azhar \& Iqbal (2018) yang menyatakan proses manajemen kelas, mengunggah tugas dan komunikasi melalui fitur "announcement" dan kolom komentar mengunakan platform Google Classroom sangat efektif.

Mahasiswa dapat mempelajari materi kembali kapan saja menggunakan platform Google Classroom menunjukkan hasil 90,18\% dengan ketegori sangat efektif. Hasil tersebut menunjukan bahwa penggunaan platform Google Classroom memudahkan mahasiswa untuk mempelajari kembali materi mata kuliah aplikasi komputer kapan saja karena platform Google Classroom yang terintegrasi dengan Google Drive dan Email secara otmatis menyimpan materi, data serta tugas khususnya pada mata kuliah aplikasi komputer sehingga sangat membantu mahasiswa ketika suatu saat kembali dibutuhkan. Pendapat tersebut didukung penelitian Pratama \& Sopryadi (2016) menyatakan mahasiswa dapat melihat file ataupun tugas yang secara otomatis telah tersimpan pada Google Drive, yang artinya penggunaan platform Google Classroom dapat meningkatkan pengorganisasian. Rohaeti (2020) dalam peneltiannya menyebutkan bahwa pada platform Google Classroom terdapat fitur "kursus arsip" sehingga memudahkan dosen mengarsipkan data, file, materi dan penugasan sehingga kapanpun dapat dilihat kembali dengan cepat saat dibutuhkan. Melalui platform Google Classroom, mahasiswa secara mandiri dapat mempelajari materi yang telah diunggah oleh dosen pada kelas Google Classroom yang dibuat (Gunawan \& Sunarman, 2017).

Mahasiswa dapat menyelesaikan tugas dengan tepat waktu menggunakan platform Google Classroom menunjukkan hasil 90,18\% dengan kategori sangat efektif. Persentase tersebut menunjukkan penggunaan platform Google Classroom sangat membantu mahasiswa karena dengan menggunakan platform Google Classroom mahasiswa dapat melihat deadline tugas yang diberikan oleh dosen dengan jelas yang akan dijadikan acuan mengerjakan tugas khususnya mata kuliah aplikasi komputer. Selain itu Google Classroom yang terinterasi dengan Google Docs sangat membantu dan memudahkan mahasiswa mengerjakan tugas dalam satu tempat. Ramadhani \& Gustin (2020) dalam penelitiannya menunjukkan hasil sangat positif, dimana dengan menggunakan platform Google Classroom mahasiswa berpendapat bahwa tugas mereka dapat terselesaikan dengan cepat. Dalam penelitiannya Utami (2019) menyebutkan bahwa kemudahan dalam mengakses platform Google Classroom melalui PC maupun Smartphone dapat mempersingkat waktu pengerjaan serta pengumpulan tugas.

Berakhirnya pembelajaran menggunakan platform Google Classroom berakhir sesuai jadwal menunjukkan hasil $86,18 \%$ dengan kategori sangat efektif. Hasil tersebut menunjukkan bahwa berakhirnya 
kegiatan pembelajaran mata kuliah aplikasi komputer menggunakan platform Google Classroom telah sesuai dengan jadwal perkuliahan. Dengan adanya deadline pengumpulan tugas pada Google Classroom memotivasi mahasiswa agar segera menyelesaikan tugasnya sebelum deadline. Dengan begitu pembelajaran menjadi semakin disiplin. Sehingga menghemat waktu baik bagi dosen dan mahasiswa. Pernyataan tersebu sejalan dengan penelitian Setyaningsih \& Hidayat (2021) meyebutkan dengan menggunakan Google Classrrom dosen dapat mengemat waktu dan mudah memanage waktu untuk mengajar.

Dengan demikian dapat diketahui bahwa penggunaan platform Google Classroom sangat efektif digunakan sebagai media pembelajaran yang mengkombinasikan antara materi dan praktik. Meski mata kuliah aplikasi komputer terdapat praktik, mahasiswa mampu menyelesaikan penugasan yang diberikan oleh dosen dengan memperhatikan dan memahami video yang di upload oleh dosen. Mahasiswa juga dapat mempelajari dan memutar kembali video kapanpun sehingga mereka lebih memahami materi yang dibuktikan dengan nilai hasil belajar mereka yang baik. Keterbatasan pada penelitian ini adalah hanya menganalisis efektivitas penggunaan google classroom pada saat proses pembelajaran berlangsung secara daring (dalam jaringan),tidak secara langsung melihat mahasiswa mempraktikan sendiri materi dalam menyelesaikan penugasasan karena keterbatasan platform Google Classroom yang tidak dapat digunakan untuk video conference. Namun tetap hal tersebut tidak mengurangi kualitas dari penelitian.

\section{KESIMPULAN}

Hasil analisis 4 indikator data diatas memperoleh rata - rata sebesar 85,49\% menunjukkan penggunaan platform Google Classroom sangat efektif sebagai media pembelajaran mata kuliah aplikasi komputer mahasiswa prodi pendidikan administrasi perkantoran universitas negeri Surabaya. Tingkat pengajaran memperoleh rata -rata persentase sebesar $87,64 \%$ dengan kategori sangat efektif. Insentif memperoleh rata rata persentase sebesar 80,22\% dengan kategori efektif. Dan indikator waktu yang menunjukkan hasil tertinggi diantara 4 (empat) indikator lain memperoleh rata - rata persentase sebesar 87,85\% dengan kategori sangat efektif. Mahasiswa dapat mempelajari kembali materi pada Google Classroom kapanpun sehingga mahasiswa lebih memahami materi pembelajaran dan kemudahan mahasiswa dalam menyelesaikan serta mengirim penugasan yang diberikan oleh dosen dengan hasil (nilai) yang baik dengan tepat waktu menunjukkan paltform Google Classroom sangat efektif digunakan sebagai media pembelajaran pada mata kuliah yang mengkombinasikan antara materi dan praktik. Keterbatasan peneliti ini adalah hanya menggunakan mahasiswa 1 (satu) angkatan mahasiswa administrasi perkantoran Fakultas Ekonomi Universitas Negeri Surabaya. Saran penulis untuk penelitian selanjutnya adalah dapat menambahkan variabel penelitian yang juga berkaitan. Selanjutnya saran untuk instansi agar tetap mempertahankan metode pembelajaran daring menggunakan platform Google Classroom sebagai media pembelajaran mata kuliah aplikasi komputer selama pandemi Covid-19. Namun alangkah lebih baiknya jika dosen dapat melihat secara langsung mahasiswa praktik.

\section{DAFTAR PUSTAKA}

Abid Azhar, K., \& Iqbal, N. (2018). Effectiveness Of Google Classroom: Teachers' Perceptions. Prizren Social Science Journal, 2(2), 52-66.

Achmad Imam, T. R. H. S. E. I. (2020). Media E-Learning Berbasis Google Classroom Untuk Meningkatkan Hasil Belajar Siswa Smk. Jurnal Pendidikan Teknik Elektro, 9(3), 605-6010.

Ali, S., \& Hamidah, A. (2020). Pembelajaran Daring Di Tengah Wabahcovid-19(Online Learning In The Middle Of The Covid-19 Pandemic). Biodik: Jurnal Ilmiah Pendidikan Biologi, 6(2), 187-192. Https://Doi.Org/Https://Doi.Org/10.22437/Bio.V6i2.9759 
Arikunto, S. (2010). Prosedur Penelitian: Suatu Pendekatan Praktik. Rineka Cipta.

Arikunto, S. (2013). Prosedur Penelitian. Rineka Cipta.

Brock, A. (2015). "Introduction To Google Classroom: An Easy-Touse Guide To Taking Your Classroom Digital.Createspace Independent Publishing Platform."

Bute, A. (2020). Google Classroom: A Subtitute To Classroom Teaching In Engineering Colleges. Research Journal Of English Language And Literature (Rjelal), 8(2), 240-244. Https://Doi.Org/10.33329/Rjelal.8.2.240

Chan, N. N., Walker, C., \& Gleaves, A. (2015). An Exploration Of Students' Lived Experiences Of Using Smartphones In Diverse Learning Contexts Using A Hermeneutic Phenomenological Approach. Computers And Education, 82, 96-106. Https://Doi.Org/10.1016/J.Compedu.2014.11.001

Destyana, V. A., \& Surjanti, J. (2021). Efektivitas Penggunaan Google Classroom Dan Motivasi Belajar Terhadap Hasil Belajar Peserta Didik Mata Pelajaran Ekonomi. Edukatif: Jurnal Ilmu Pendidikan, 3(3), 1000-1009. Https://Edukatif.Org/Index.Php/Edukatif/Index

Fauzan, F., \& Arifin, F. (2019). The Effectiveness Of Google Classroom Media On The Students' Learning Outcomes Of Madrasah Ibtidaiyah Teacher Education Department. Al Ibtida: Jurnal Pendidikan Guru Mi, 6(2), 271. Https://Doi.Org/10.24235/Al.Ibtida.Snj.V6i2.5149

Gikas, J., \& Grant, M. M. (2013). Mobile Computing Devices In Higher Education: Student Perspectives On Learning With Cellphones, Smartphones \& Social Media. Internet And Higher Education, 19, 18-26. Https://Doi.Org/10.1016/J.Iheduc.2013.06.002

Gunawan, F. I., \& Sunarman, S. G. (2017). Pengembangan Kelas Virtual Dengan Google Classroom Dalam Keterampilan Pemecahan Masalah (Problem Solving) Topik Vektor Pada Siswa Smk Untuk Mendukung Pembelajaran. Prosiding Seminar Nasional Etnomatnesia, 340-348.

Hakim, A. B. (2016). Efektifitas Penggunaan E-Learning Moodle, Google Classroom Dan Edmodo. IStatement, 2 (1), 1-6.

Harandi, S. R. (2015). Effects Of E-Learning On Students' Motivation. Procedia - Social And Behavioral Sciences, 181(October), 423-430. Https://Doi.Org/10.1016/J.Sbspro.2015.04.905

Heggart, K. R., \& Yoo, J. (2018). Getting The Most From Google Classroom: A Pedagogical Framework For Tertiary Educators. Australian Journal of Teacher Education, 43(3), 140-153. Https://Doi.Org/10.14221/Ajte.2018v43n3.9

Henukh, A., Rosdianto, H., \& Oikawa, S. (2020). Implementation Of Google Classroom As Multimedia Learning. Jipf (Jurnal Ilmu Pendidikan Fisika), 5(1), 38. Https://Doi.Org/10.26737/Jipf.V5i1.1539

Jannatu, N. N., Supartono, \& Wardani, S. (2015). Penerapan Pembelajaran Berbasis Proyek Berbantuan ELearning Uuntuk Meningkatkan Hasil Belajar Siswa. Jurnal Inovasi Pendidikan Kimia, 9(2), 15661574.

K.Y.S. Putri, W. H. (2020). Efektivitas Komunikasi Google Classroom Sebagai Media Pembelajaran Jarak Jauh Pada Mahasiswa Ilmu Komunikai Universitas Negeri Jakarta Angkatan 2018. Medialog: Jurnal Ilmu Komunikasi, 3(2), 24-35. Https://Doi.Org/10.35326/Medialog.V3i2.639

Kay, R. H., \& Lauricella, S. (2011). Exploring The Benefits And Challenges Of Using Laptop Computers In Higher Education Classrooms: A Formative Analysis. Canadian Journal Of Learning And Technology / La Revue Canadienne De L'apprentissage Et De La Technologie, 37(1). Https://Doi.Org/10.21432/T2s598

Kim, K. J., \& Frick, T. (2011). Changes In Student Motivation During Online Learning. Journal Of Educational Computing Research, 44(1), 1-23. Https://Doi.Org/10.2190/Ec.44.1.A

M. A. P. Burac. (2019). Assesing The Impact Of E-Learning System Of Higher Education Institution's Instructors And Students. Iop Conference Series: Material Science And Engineering, 482, 1-8. 
Manizar, E. (2017). Peran Guru Sebagai Motivator Dalam Belajar. Tadrib: Jurnal Pendidikan Agama Islam, $1(2), 204-222$.

Muhardi, \& Ponidi. (2020). Pembelajaran Online Yang Efektif Di Masa Pandemi Covid-19 Studi Kasus Di Smp Negeri 4 Pakem Sleman. Jurnal Intek, 3(1), 41-51.

Nana Sudjana. (1990). Teori-Teori Belajar Untuk Pengajaran. Fakultas Ekonomi Ui.

Okmawati, M. (2020). The Use Of Google Classroom During Pandemic. Journal Of English Language Teaching, 9(2), 438. Https://Doi.Org/10.24036/Jelt.V9i2.109293

Pratama, D., \& Sopryadi, H. (2016). Analisis Pengaruh Pemanfaatan Google Classroom Terhadap Efisiensi Pada Stmik Xyz. Seminar Nasional Teknologi Informasi.

Ramadhani, S., \& Gustin, E. (2020). Tanggapan Mahasiswa Terhadap Pemanfaatan Google Classroom Sebagai Media Pembelajaran Online. Justin (Jurnal Sistem Dan Teknologi Informasi), 8(3), 278-281. Https://Doi.Org/10.26418/Justin.V8i3.40007

Riduwan. (2018). Dasar-Dasar Statistika. Bandung: Alfabeta.

Rohaeti, T. (2020). Respon Mahasiswa Pendidikan Matematika Dalam Penggunaan Google Classroom Di Era Covid-19. Integral: Pendidikan Matematika, 11(1), 6-68.

Sabran, \& Sabara, E. (2019). Keefektifan Google Classroom Sebagai Media Pembelajaran. Prosiding Seminar Nasional Lembaga Penelitian Universitas Negeri Makasar, 122-125. Https://Webcache.Googleusercontent.Com/Search?Q=Cache:Ss_Jkm_R2taj:Https://Ojs.Unm.Ac.Id/Sem naslemlit/Article/Download/8256/4767+\&Cd=2\&Hl=Id\&Ct=Clnk\&Gl=Id

Salamor, J. M. (2017). Hubungan Antara Pemberian Reward Dari Guru Dengan Motivasi Berprestasi Siswa Di Sma Kristen Halmahera Utara. Hibualamo : Seri Ilmu-Ilmu Sosial Dan Kependidikan, 1(1), 21-29.

Sari, I. N. (2019). Terhadap Efektivitas Pembelajaran Mahasiswa Universitas Islam Indonesia Skripsi Oleh : Nama No . Mahasiswa : Isna Normalita Sari Fakultas Ekonomi Universitas Islam Indonesia Yogyakarta. 1-120. Https://Dspace.Uii.Ac.Id/Bitstream/Handle/123456789/13733/Isna Normalita Sari.Pdf?Sequence $=1 \&$ Isallowed $=\mathrm{Y}$

Setyaningsih, W. D., \& Hidayat, S. (2021). Pedadidaktika: Jurnal Ilmiah Pendidikan Guru Sekolah Dasar Analisis Penggunaan Aplikasi Google Classroom Sebagai Media Pembelajaran Dalam Meningkatkan Keaktifan Siswa. 8(3), 727-741.

Slavin, R. E. (2008). Psikologi Pendidikan Teori Dan Praktik. Jawa Tengah:Pt Macanan Jaya Cemerlang.

Sukmadinata, N. S. (2015). Metode Penelitian Pendidikan. Pt Remaja Rosdakarya.

Utami, R. (2019). Analisis Respon Mahasiswa Terhadap Penggunaan Google Classroom Pada Mata Kuliah Psikologi Pembelajaran Matematika. Prisma, Prosiding Seminar Nasional Matematika Issn 2613-9189, 2, 498-502. Https://Journal.Unnes.Ac.Id/Sju/Index.Php/Prisma/Article/View/29040

Widiyono, A. (2020). Efektifitas Perkuliahan Daring (Online) Pada Mahasiswa Pgsd Di Saat Pandemi Covid 19. Jurnal Pendidikan, 8(2), 169-177. Https://Doi.Org/10.36232/Pendidikan.V8i2.458

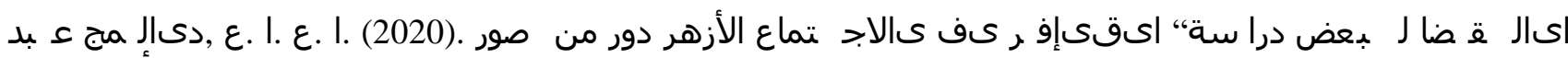

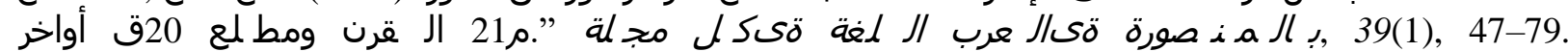
Https://Doi.Org/10.21608/Jflm.2020.134615 